\title{
音声外科の立場から \\ ——声帯への手術侵襲と術後の声帯振動——
}

\section{湯本英二}

要 約：過去 11 年間に入院の上でおこなった音声外科的治療の内訳は喉頭微細手術が 366 例, 喉頭枠組みの手術 29 例, 間接喉頭鏡下手術 11 例, その他 4 例と圧倒的に喉頭微細手術が 多かった。そこで, 声帯に加えた微細な手術操作が声帯振動に及ほす影響を高速度映画撮影に よって検討した。(1)正常例：下唇, 遊離縁とも振動は対称的であった。下唇は遊離縁となって 正中で左右が合した後, 速やかに外側へ移動した。その後, 左右の遊離縁が離開を始めるまで 外側に留まり, 遊離縁の外方への移動中に内方への動きを開始した。 (2)声帯操作例：声帯膜様 部の上面あるいは下面のどちらに創を作製した場合でも，操作側遊離縁の振動は，振幅が小さ くなり，位相は早くなる場合が多かった。操作側下唇の振動は，外方への動きが遅くなり，ま た，声帯上面の創でも大きいときは下唇の消失することがあった。声帯下面に創を作製した場 合，健側遊離縁の振動も不規則になる場合が観察された。

索引用語 : 音声外科, 声帯への手術侵襲, 高速度映画, 声帯振動, 声帯下面

\section{Vocal Fold Vibration After Microsurgery of the Larynx}

\section{Eiji Yumoto, M.D.}

\begin{abstract}
The author investigated the influence of microsurgical intervention of the canine larynx to vocal fold vibration. (1) Normal case : bilateral lower lips and free edges vibrated symmetrically. Lower lips coincided with free edges and met together at the midline. Then, lower lips rapidly moved apart laterally. They stayed at the most lateral points until both free edges started to move apart laterally. After that, they began to move medially to meet together again when free edges were moving away laterally. (2) Cases after microsurgical intervention: a part of the mucosal layer of the upper surface or the lower surface of the vocal fold was removed. Several weeks after the procedures, vibration was observed. In either case, vibration of the free edge of the operated vocal fold became smaller in amplitude and often became earlier in phase than that of the other side.Usually lower lip of the operated vocal fold moved away slower. In addition, when the extent of epithelial removal was large vibration of lower lip was not elicited.
\end{abstract}

Key words : Phonosurgery, Microsurgery of the vocal fold, High speed movie, vocal fold vibration, Lower surface of the vocal fold 


\section{I.はじめに}

発声機能を取り扱う音声外科は, 多くの場合, 音声 の改善を目的としておこなわれ，その手法は次のよう に分類される.すなわち，(1)喉頭内腔からのアプロー チによる病的組織の除去，これには一般にラリンゴマ イクロと呼ばれる顕微鏡下喉頭微細手術と間接喉頭鏡 下手術が含まれる。(2)声帯に直接触れることなく声帯 の位置・形態・緊張を矯正する手術で, 甲状軟骨形成 術に代表される喉頭枠組みの手術である. 以下, (3)喉 頭の神経・筋の機能改善手術, (4)喉頭の部分的欠損・ 変形に対する機能再建手術, (5)喉頭の全欠損に対する 機能再建手術がある。

本稿では, まず著者らの行っている音声外科的手術 を紹介し, 次に, 手術件数の最も多い顕微鏡下喉頭微 細手術における手術操作が声帯振動に及ぼす影響を成 犬を用いた実験によって主に声帯下面から観察検討し た。

\section{II. 当科における音声外科的治療}

昭和 51 年 10 月から昭和 62 年 9 月までの 11 年間に 入院の上で音声外科的治療を行った, 延べ 424 例を対 象にして当科における音声外科的治療の現況を述べ た.

表 1 に疾患別の内訳を示す。非腫瘍性疾患ではポリ ープが最も多く, 以下ポリープ様声帯, 声帯結節, 反 回神経麻舫の順であった．腫瘍性疾患では白板症等の 上皮過形成症，成人あるいは幼児の乳頭腫，喉頭癌等 があげられた。なお同一患者で病名の重複するものが

表 1 当科において音声外科的治療 を行った，延べ 424 例の疾患 別内訳

\begin{tabular}{lr}
\hline ポリープ & 127 (例) \\
ポリープ様声帯 & 74 \\
声帯結節 & 41 \\
反回神経麻疩 & 30 \\
横隔膜 & 11 \\
肉芽腫 & 14 \\
声帯溝症・萎縮 & 9 \\
過緊張性発声障害 & 6 \\
喉頭癌 & 38 \\
乳頭腫・白板症等 & 71 \\
その他 & 27 \\
\hline \multicolumn{2}{r}{ 計 } \\
\hline
\end{tabular}

若干みられた。性別では全体として男性の方が女性よ り約 $40 \%$ 多く, 年齢では男性が 50 歳台, 女性が 40 歳 台にピークがあった。

治療手段では喉頭内腔からのアプローチ，とりわけ ラリンゴマイクロが 366 例と大多数を占めていた。 下，喉頭枠組の手術が 29 例，間接喉頭鏡下手術が 11 例，その他 4 例であった。間接喉頭鏡下手術は現在で は全身麻酔がかけられない例などに行われるにすぎな い. また，通常の方法によるラリンゴマイクロの他に， 最近ではレーザーを用いる方法や，従来のシリコンに かわってアテロコラーダンを声帯に注入する方法を行 っているので簡単に紹介した。

著者らは主に炭酸ガスレーザーを用いており，アダ プターを介して手術用䫓微鏡に装着して使用する。適 応疾患は喉頭癌, 乳頭腫, 白板症等の上皮過形成症, 声帯横隔膜症, 外傷性瘢痕などである。詳細は参考文 献に袞る ${ }^{1,2)}$.

声帯内注入剤としてのアテロコラーゲンは，仔牛真 皮から抽出された異種蛋白ではあるが抗原性はほとん ど認められない，教室の岡本は成犬を用いた基礎実験 から，声带注入剤としてのアテロコラーゲンの有用性 および安全性を確認した ${ }^{3)}$ ので著者らは昭和 61 年 7 月より臨床に応用してきた。昭和 62 年 9 月までに片側 反回神経麻痺 ( 7 例), 声带溝症 ( 2 例), 声帯萎縮 ( 1 例), 喉頭外傷（1例）の 11 例にアテロコラーゲン注 入を施行した。本法の実際，注入前後の発声機能等に ついては別稿で報告すべく準備中である.

\section{III。手術操作が声帯振動に及ぼす影響 声帯下面の観察を中心に}

\section{1. 方 法}

実際には成犬を用いた。実験の前段階として，実際 のラリンゴマイクロを模して顕微鏡下に一側声帯膜様 部中央の上面あるいは下面に浅く小さな創を作製し た。創が上皮化した後，喉頭を吹鳴し声帯上面および 下面から秒速約 5,000 駒で高速度映画を撮影した。吹 鳴に際して両側声帯軟骨部を 4-0ナイロン系で縫合 した. 声帯振動を撮影したフイルムは 1 駒ごとに Film Motion Analyzer を用いて解析した。

気管側からの声帯下面の撮影には摘出喉頭を用い た。喉頭をガラス箱にあけた小孔に固定し，ガラス箱 を通して吹鳴し，吹鳴が非生理的とならないように工 夫した，吹鳴音はテープに録音し，ピッチ，ピッチの ゆらぎ， $\mathrm{H} / \mathrm{N}$ 比 ${ }^{4)}$ 測定した。なお， $\mathrm{H} / \mathrm{N}$ 比測定のた めに同定した 50 個の周期について瞬時周波数を計算 
し, 相隣合う瞬時周波数の差の平均を平均周波数で除 したものを百分率表示してピッチのゆらぎの指槽とし た、時間の制約のため声带下面の振動についてのみ報 告した。

\section{2. 声帯上面と下面の関係}

吹鳴に用いた喉頭をホルマリンで充分固定し声带位 が不動となった後にナイロン系を除去し喉頭を正中で 切断した。図 1 は右側喉頭を正中側からみた写真であ る。発声時, 声带上面と下面は平行でなく, 両者の間 には25度前後の角度がある。また，下面からみた声带 前端は上面のそれに比して後方にみえる。したがって， 声带下面の振動の観察には喉頭気管の長軸より後方か

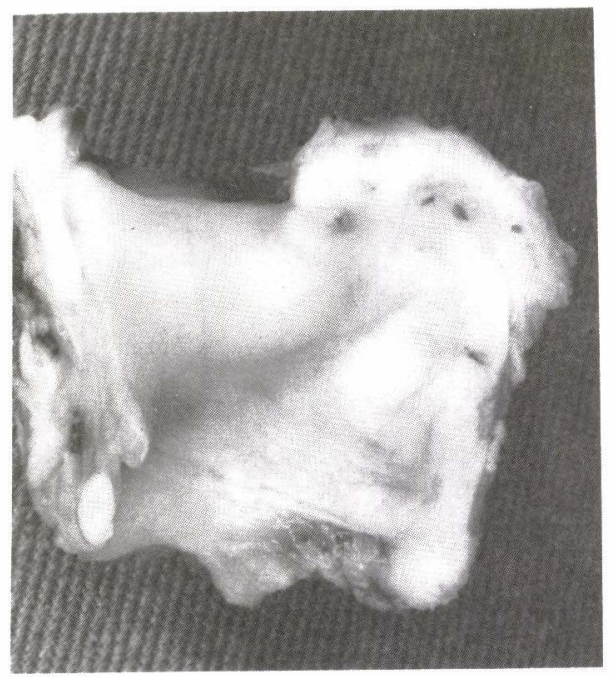

図 1 右側喉頭を正中側からみた写真 発声時, 声帯上面と下面は平行でないことがわかる.
らみる必要があった。

\section{3. 結 果}

まず正常例について述べた。声带下面撮影時の吹鳴 音はピッチ $191 \mathrm{H}_{Z}$, ピッチのゆらぎ $1.0 \%, \mathrm{H} / \mathrm{N}$ 比 $10.4 \mathrm{~dB}$ であった。下面からみて最大振幅を示す部分 で両側の下唇と遊離縁の動きを分析した。声帯振動の 1 周期中に声帯縁の付近に唇状の隆起が 2 つ現れる. 上の隆起を上唇，下の隆起を下唇と称する。上唇，下 唇は声帯上の特定の部位ではなく，これらの唇状隆起 が生じる部位は振動の伝搬とともに移動する。閉小期 には下唇が上唇より内方にあり，気管側からみると上 唇流観察されなくなる。開大期および閉鎖期の大部分 において遊離縁は上唇の振動に等しい.

図 2 に気管側からみた声帯下面の振動を示す。上が 左側，下が右側で，外側の線が下唇の動きを，内側の 線が遊離縁の動きを表す。下唇, 遊離縁とも振動は対 称的であった。下唇は遊離縁となって正中で左右が合 した後, 速やかに外側へ移動した。 その後, 左右の遊 離縁が離開を始めるまで外側に留まり, 遊離縁の外方 への移動中に内方への動きを開始した。なお，声带振 動は，声門下腔との間に生じた段差すなわちヒダ状粘 膜隆起の内方で起こり, それより外方あるいは下方の 粘膜は振動しない，正常例では下唇の外方への振動は この七ダ状粘膜隆起にまで至る。

次に右声带膜样部中央の上面に小さな浅い創を作製 した場合について述べ。振動の分析点は気管側から みて最大振幅を示す部位で両側の遊離縁と下唇とし た。図 3 に本例の声带振動を示す。下が創を作製した 右声帯の振動を表す。操作側は遊離緑, 下唇とも振幅 が健側よりも小さくなった。遊離縁の外方移動は操作

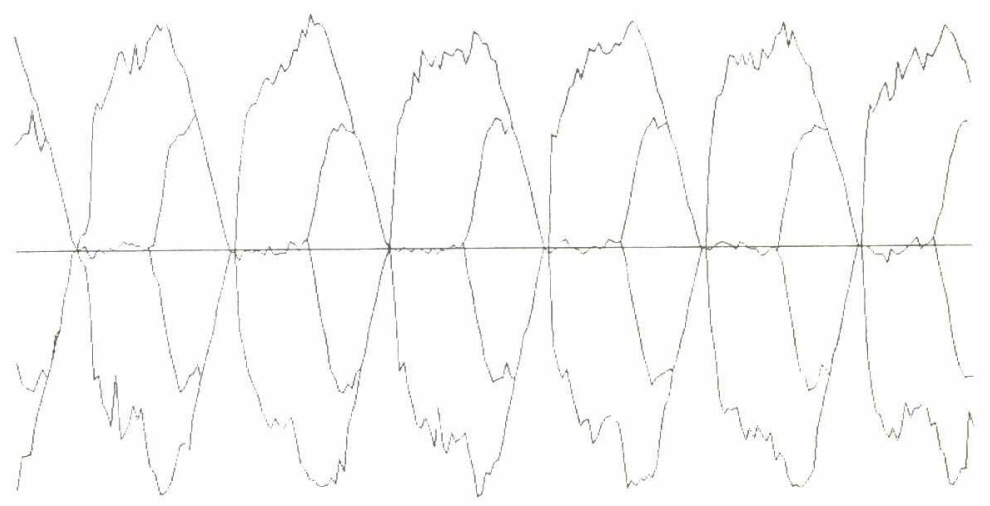

図2 正常例の, 気管側からみた声带下面の振動

上が左側，下が右側の振動を，外側の線が下唇の

動きを, 内側の線が遊離縁の動きを表す。図 $3 \sim 5$

についても同様。 


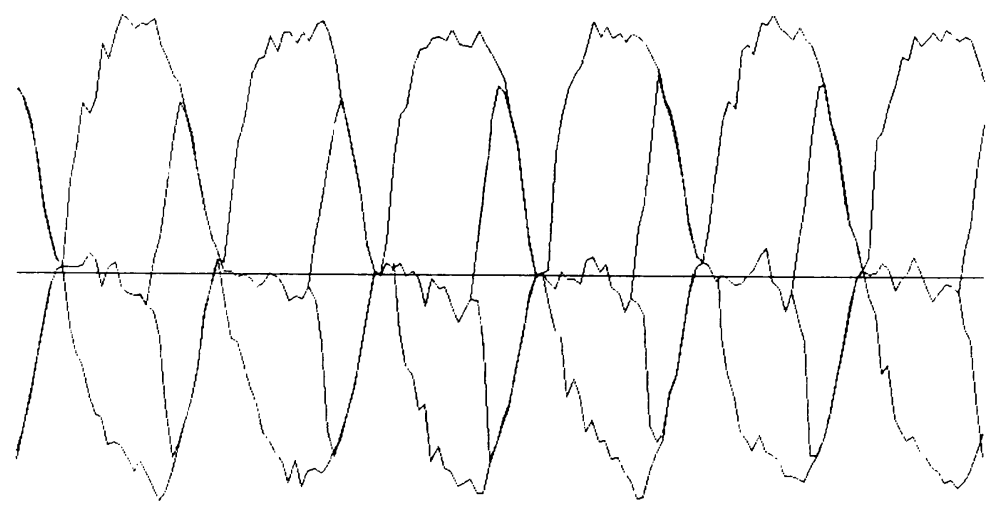

図3 右声帯膜様部中央の上面に小さな浅い創を作 製した例の声帯下面の振動

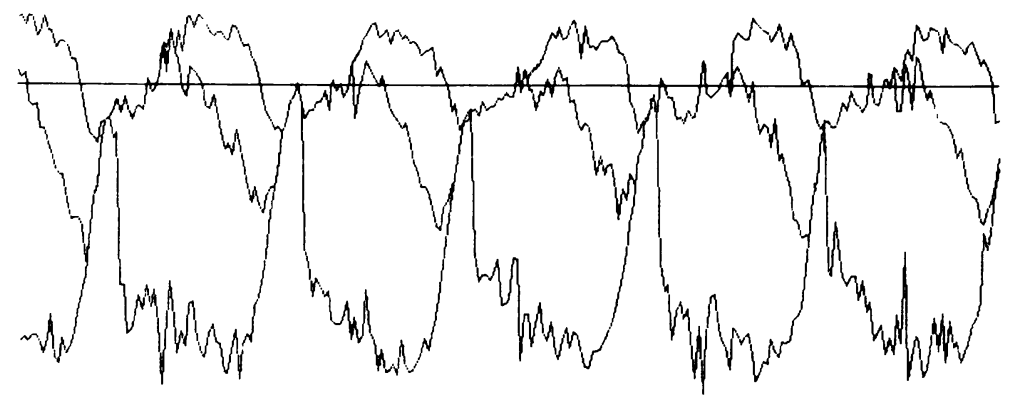

図 4 左声帯膜様部中央の上面に先の例より広く, しかし浅い創を作製した例の声帯下面の振動

側がやや早くなった。また，操作側下唇の外方移動は 速さがかなり制限され, 健側のように最外方でしばら く留まることはなかった。しかしながら吹鳴音はピッ チ $129 \mathrm{~Hz}$, ピッチのゆらぎ $0.5 \%, \mathrm{H} / \mathrm{N}$ 比 $14.7 \mathrm{~dB}$ と まったく正常であった。

左声帯膜様部中央の上面に先ほどより広く, しかし 浅い創を作製した。操作側である左声帯の下唇はまっ たく惹起されなかった。したがって振動の分析点は, 気管側からみて最大振幅を示す部分で両側の遊離縁と 右下唇とした。図 4 に本例の声帯振動を示す.上が操 作側である左声帯の振動を表す。遊離縁の振動は振幅 がかなり小さくなり, 位相が早くなった. 下唇の振動 はまったく惹起されなかった，吹鳴音はピッチ 147 $\mathrm{Hz}$, ピッチのゆらぎ $1.2 \%, \mathrm{H} / \mathrm{N}$ 比 $2.7 \mathrm{~dB}$ とかなり 雑音成分の増加がみられた。声帯上面の創によって, 声帯下面の粘膜はまったく正常であるにもかかわらず 下唇が消失したという結果は注目に值する.

最後に右声帯膜様部中央の下面に小さな浅い創を作 製した場合について述べた，高速度カメラの位置がや や左側に片寄ったので健側である左声帯の外側が視野
からずれ健側の下唇の振動の一部を撮影できなかつ た.したがって振動の分析点は，気管側からみて最大 振幅を示す部分で両側の遊離縁と右下唇とした。図 5 に本例の声帯振動を示す。下が操作を加えた右声帯の 振動を表す。遊離縁の振動は，振幅には左右差があま りみられないものの, 両側とも各周期ごとに不規則な 乱れが認められた。この例では操作側である右声帯の 位相がやや遅れていた。下唇の振動は振幅が小さくな り粘膜隆起まで到達しなかった，吹鳴音はピッチ 193 $\mathrm{Hz}$, ピッチのゆらぎ $1.4 \%, \mathrm{H} / \mathrm{N}$ 比 $7.1 \mathrm{~dB}$ とやや悪 化していた。

\section{4.まとめ}

声帯膜様部の上面あるいは下面のどちらに創を作製 した場合でも, 操作側遊離縁の振動は, 振幅が小さく なり，位相は早くなる場合が多く観察された．操作側 下唇の振動は, 外方への動きが遅くなり, また, 声帯 上面の創でも大きいときは下唇の消失することがあっ た.

声帯下面に創を作製した場合，健側遊離緑の振動も 不規則になる場合が観察された. 


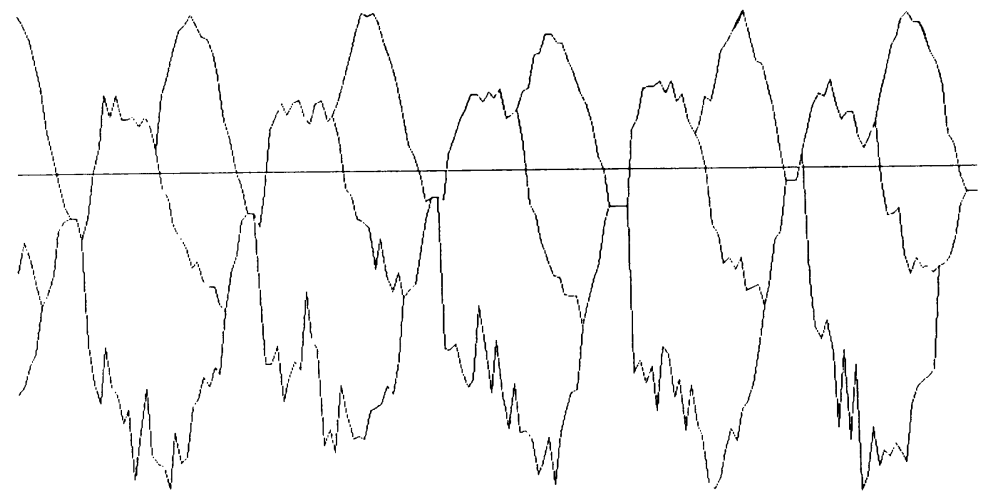

図 5 右声帯膜様部中央の下面に小さな浅い創を作 製した例の声帯下面の振動

\section{IV.おわりに}

先に述べたいくつかの音声外科的手法のなかで顕微 鏡下喉頭微細手術の行われることが圧倒的に多い. 声 帯に手術操作を加えた後の創傷治癒に関する形態学的 研究は少ないながらもいくつか散見される し，創傷治癒後の声帯振動を系統的に分析した報告は みられない。著者は創傷治癋後の声帯振動を声帯上面 と下面の両面について高速度映画を用いて検討し, 若 干の知見を得たので報告した。特に, 声帯上面からの 撮影では検出できない, 下唇の振動の変化を中心に報 告した。今後さらに詳細な検討を行う予定である.

(共同研究者: 岡本和憲, 河村裕二, 黒川浩伸)

\section{文献}

1）湯本英二, 岡本和憲, 河村裕二, 丘村 熙: 喉頭 癌治療におけるレーザー手術の応用と術後発声機
能. 日耳鼻, $88 ： 728-733 ， 1985$.

2) 丘村 熙, 湯本英二, 岡本和憲, 河村裕二 : 喉頭 のレーザー外科. 日気食会報, 37：141-146, 1986.

3）岡本和憲：声門閉鎖不全に対するアテロコラーゲ ン声帯内注入療法に関する基礎的研究. 日耳鼻, $90: 394-403,1987$.

4）湯本英二：嗄声度の定量的指標に関する研究.耳 鼻臨床, $76: 2151-2168,1983$.

5）北原哲, 福田宏之, 鈴木安恒, 秋田谷直, 他： Laryngomicrosurgery の基礎的研究 (声帯損傷の 病理組織学的研究)。日気食会報, $22: 11-14,1971$.

6) 平野実: 声帯の損傷と回復に関する実験的研 究。耳鼻と臨床, 21 (補冊 1)：299-306, 1975.

7）大築淳一：声帯創傷治療に関する基礎的研究. 耳 鼻と臨床, $28: 53-65,1982$.

8）丘村 熙: 声帯組織への手術侵襲と治瘺機転。6 63 -82 頁. 平野 実編「音声外科における最新の進 歩」. 医学教育出版社, 1984. 